\title{
PENGARUH JURNAL BELAJAR TERHADAP HASIL BELAJAR KIMIA MATERI HIDROKARBON
}

\author{
Annisa Septian Nurkhasanah*, Mukhtar Haris, Jeckson Siahaan \\ Program Studi Pendidikan Kimia, Universitas Mataram. Jalan Majapahit No. 62 \\ Mataram, NTB 83112, Indonesia. \\ * Coressponding Author. E-mail: annanurkhasanah@ymail.com
}

Received: 12 Desember 2019

Accepted: 15 Mei 2020

Publish: 29 Mei 2020

doi: 10.29303/cep.v3i1.1546

\begin{abstract}
Abstrak
Penelitian ini bertujuan untuk mengetahui pengaruh penggunaan jurnal belajar dan perbedaan antara pembelajaran menggunakan jurnal belajar dengan pembelajaran tanpa menggunakan jurnal belajar terhadap hasil belajar kimia materi hidrokarbon pada siswa kelas XI MIA SMAN 8 Mataram. Jenis penelitian yang digunakan adalah penelitian eksperimen semu dengan desain penelitian posttest only-nonequivalent control group design. Populasi dalam penelitian ini adalah seluruh siswa kelas XI MIA SMAN 8 Mataram. Sampel dalam penelitian ini yaitu kelas XI MIA 2 dan XI MIA 4 yang ditentukan melalui teknik pengambilan sampel Purposive Sampling. Variabel bebas dalam penelitian ini adalah jurnal belajar dan variabel terikatnya adalah hasil belajar kimia siswa dalam ranah kognitif. Teknik pengumpulan data dilakukan dengan pemberian posttest dalam bentuk tes pilihan ganda untuk mengukur hasil belajar siswa. Pengujian hipotesis dilakukan dengan menggunakan uji U-test dengan pengambilan keputusan didasarkan pada uji hipotesis dua pihak. Uji U-test digunakan untuk menganalisis data hasil belajar kimia siswa, didapatkan Zhitung $(3,39)>$ Ztabel $(1,64)$. Hasil tersebut menunjukkan bahwa pembelajaran menggunakan jurnal belajar pada pelajaran kimia materi hidrokarbon memberikan hasil belajar yang lebih baik daripada tanpa menggunakan jurnal belajar pada siswa kelas XI MIA SMAN 8 Mataram.
\end{abstract}

Kata kunci : jurnal belajar, hasil belajar, materi hidrokarbon

\section{The Effect of Learning Journal on Chemistry Learning Outcomes on Hydrocarbon Subject Matter}

\begin{abstract}
This study aims to determine the effect of the use of learning journals and the difference between learning using learning journals and learning with out using learning journals on chemistry learning out comes on hydrocarbon subject matter for XI MIA students of SMAN 8 Mataram. The type of this study is a quasi-experimental using the post test only-nonequivalent control group design. The population in this study are all students of XI MIA SMAN 8 Mataram. The samples in this study are the students of XI MIA 2 and XI MIA 4 which are determined through Purposive Sampling technique. The independent variable in this study is the learning journal and the dependent variable is the students chemistry learning out comes in the cognitive realm. Data collection techniques are done by giving a posttest in the form of multiple choice tests to measure student learning out comes. Hypothesis testing is done by using a U-test in which the decision making based on a two-party hypothesis test. U-test was used to analyze the data of student chemistry learning out comes, which obtained Zcount (3.39) > Ztable (1.64). These results in dicate that learning using learning journal in chemistry learning for the subject matter of hydrocarbon provides better learning outcomes than without using learning journal in XI MIA students of SMAN 8 Mataram.
\end{abstract}

Keywords : learning journal, learning outcomes, hydrocarbon subject matter 


\section{PENDAHULUAN}

Belajar merupakan suatu proses yang ditandai dengan adanya perubahan pada diri seseorang. Perubahan tersebut sebagai hasil belajar dan ditunjukkan dalam berbagai bentuk seperti perubahan pengetahuan, pemahamannya, perilakunya, daya reaksinya, daya penerimaannya, dan lain-lain aspek individu. Menurut Sudjana (dalam Darmawan dan Permasih, 2013:127), belajar tidak hanya diartikan sebagai proses yang dilakukan siswa untuk memperoleh ilmu pengetahuan dari guru, namun belajar juga memiliki aspek yang harus dicapai agar proses tersebut berjalan dengan baik.

Hasil belajar merupakan perubahan yang terjadi setelah mengalami proses pembelajaran. Menurut Daud (dalam Muhsin, dkk., 2019), hasil belajar siswa dapat diukur melalui tiga ranah yaitu melalui ranah kognitif, ranah afektif, dan ranah psikomotorik. Ketiga ranah tersebut dapat diperoleh siswa setelah melalui kegiatan pembelajaran. Hasil belajar memiliki peran penting dalam proses pembelajaran karena hasil belajar dapat memberikan informasi kepada guru tentang kemajuan siswa dalam upaya mencapai tujuan-tujuan belajarnya melalui berbagai kegiatan belajar. Selanjutnya, dari informasi tersebut guru dapat menyusun dan membina kegiatan-kegiatan siswa lebih lanjut, baik untuk keseluruhan kelas maupun individu. Hasil belajar juga didapatkan dari pengalaman belajar siswa dan menghasilkan suatu kemampuan (Sudjana, 2002).

Ilmu kimia memuat berbagai materi yang isinya relatif abstrak dan rumit. Menurut Sunyono dkk. (2009) dan Supriadi (2018), pada pembelajaran kimia umumnya penyampaian materi kimia oleh guru kepada siswa hanya dijejali informasi yang kurang konkrit dan diskusi yang kurang menarik karena bersifat teoritis serta siswa tidak pernah diberi pengalaman langsung, sehingga siswa menganggap materi pelajaran kimia adalah abstrak dan sulit dipahami.

Berdasarkan hasil observasi yang dilakukan di SMA Negeri 8 Mataram, menunjukkan bahwa masih banyak siswa yang belum aktif mengikuti proses pembelajaran di kelas dan siswa tidak memahami dan mempelajari kembali materi yang telah disampaikan oleh guru. Akibatnya nilai rata-rata hasil belajar kimia siswa kelas XI MIA masih di bawah Kriteria Ketuntasan Minimal (KKM) sebesar 75. Pada kelas X MIA 2 persentase siswa yang mendapatkan nilai diatas KKM sebesar 17,6\% dan pada kelas X MIA 4 sebesar $11,1 \%$.

Permasalahan yang muncul tersebut merupakan gambaran dari tahapan proses pembelajaran umpan balik berupa proses refleksi yang tidak terlaksana secara keseluruhan. Menurut DCU (dalam Wati dkk., 2016), refleksi merupakan cara belajar dan membantu siswa untuk mengevaluasi kinerja diri sebagai seorang pelajar. Barun dan Thomas (dalam Wati dkk., 2016) mengemukakan bahwa refleksi dapat mendorong proses kognitif sehingga dapat meningkatkan hasil belajar siswa. Menurut Ardiansyah dkk. (2019), untuk meningkatkan hasil belajar, proses pembelajaran dapat dilakukan dalam bentuk kegiatan yang mengarahkan siswa untuk bekerja dan mengalami semua proses belajar dengan selalu mengaitkan setiap materi dan memberikan penguatan pada tiap materi yang telah dipelajari. Untuk itu diperlukan strategi belajar yang dapat mendorong siswa mengkontruksikan konsepkonsep pembelajarannya sendiri

Penggunaan jurnal belajar merupakan salah satu cara meningkatkan minat belajar kimia siswa melalui proses refleksi belajar sehingga hasil belajar siswa juga dapat meningkat. Menurut Irez dan Cakir (dalam Wati dkk., 2016), melalui refleksi seseorang dapat lebih mengenali dirinya, mengetahui permasalahan dan memikirkan solusi untuk mengatasi permasalahan tersebut. Menurut Stephens dan Winterbottom (dalam Lianto dkk., 2018), menulis jurnal belajar dapat meningkatkan kognitif siswa dalam belajar dimana siswa dapat mengetahui tujuan yang ingin dicapai dan membantu siswa mengidentifikasi kelemahannya dalam belajar sehingga dapat teratasi.

Berdasarkan uraian di atas, maka perlu dilakukan penelitian yang bertujuan untuk mengetahui pengaruh jurnal belajar terhadap hasil belajar siswa dan mengetahui perbedaan pengaruh antara pembelajaran menggunakan jurnal belajar dengan pembelajaran tanpa menggunakan jurnal belajar terhadap hasil belajar kimia materi hidrokarbon pada siswa kelas XI MIA SMAN 8 Mataram.

\section{METODOLOGI PENELITIAN}

Penelitian ini adalah penelitian kuasi eksperimen. Penelitian ini telah dilaksanakan di SMA Negeri 8 Mataram untuk tahap penelitian. 
Populasi dalam penelitian adalah siswa kelas XI MIA SMAN 8 Mataram tahun ajaran 2019/2020. Sampel penelitian ditentukan melalui teknik purposive sampling dengan pertimbangan tertentu (Sugiyono, 2017). Sampel yang berjumlah 70 orang tersebar di kelas XI MIA 4 dengan perlakuan pembelajaran menggunakan jurnal belajar dan XI MIA 2 dengan perlakuan pembelajaran tidak menggunakan jurnal belajar. Rancangan penelitian yang digunakan adalah posttest only nonequivalent control group design. Data awal yang digunakan pada penelitian ini adalah nilai hasil Ulangan Akhir Semester (UAS) siswa kelas X MIA SMAN 8 Mataram pada tahun ajaran 2018/2019. Data awal yang telah didapatkan kemudian dianalisis menggunakan uji statistik yaitu uji homogenitas dan uji beda menggunakan dua pihak. Kedua uji ini digunakan untuk menentukan kelas sampel.

Selanjutnya dilakukan penelitian dengan kelas eksperimen menerapkan pembelajaran menggunakan jurnal belajar sedangkan kelas kontrol menerapkan pembelajaran tanpa menggunakan jurnal belajar pada materi hidrokarbon. Data yang dikumpulkan meliputi data hasil belajar dalam ranah kognitif. Data hasil belajar kognitif didapatkan melalui tes pilihan ganda. Instrumen tes diuji validitas yaitu uji validitas ahli menggunakan rumus Aiken's V (Azwar, 2013) dan uji validitas butir soal menggunakan rumus korelasi point biserial, selanjutnya diuji reliabilitasnya menggunakan rumus K-R.20 (Arikunto, 2010).Data hasil belajar yang telah diperoleh kemudian dianalisis menggunakan uji statistik. Uji statistik yang digunakan adalah uji homogenitas dan uji normalitas sebagai uji prasyarat, kemudian dilakukan uji hipotesis. Data yang digunakan untuk mengetahui pengaruh jurnal belajar terhadap hasil belajar adalah data posttest yang dianalisis dengan uji Mann Whitney atau uji-U pada taraf signifikan 5\% (Sugiyono, 2017).

\section{HASIL DAN PEMBAHASAN}

Hasil belajar siswa yang diberikan perlakuan untuk kelas eksperimen diperoleh nilai rata-rata posttest sebesar 71,88 dan kelas kontrol diperoleh nilai rata-rata posttest sebesar 55,82 dengan selisih nilai sebesar 16,06. Berdasarkan nilai rata-rata posttest menunjukkan bahwa kelas eksperimen yang diberi pembelajaran menggunakan jurnal belajar memiliki hasil belajar yang lebih baik dibandingkan dengan kelas kontrol yang tidak menggunakan jurnal belajar. Perbedaan tersebut didukung oleh uji hipotesis yang menunjukkan adanya perbedaan hasil belajar antara siswa menggunakan jurnal belajar dengan siswa yang tidak menggunakan jurnal belajar.

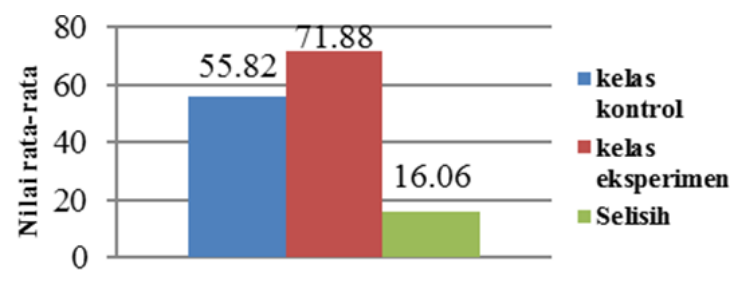

Gambar 1. Nilai rata-rata hasil posttest

Data hasil posttest diuji menggunakan uji statistik nonparametris yaitu uji Mann Whitney atau uji-U dengan pendekatan kurva normal $\mathrm{Z}$. Diperoleh nilai $Z_{\text {hitung }}>Z_{\text {tabel }}$ yang menunjukkan bahwa Ho ditolak dan Ha diterima. Hal ini menunjukkan bahwa pembelajaran menggunakan jurnal belajar pada pelajaran kimia materi hidrokarbon memberikan hasil belajar yang lebih baik daripada tanpa menggunakan jurnal belajar pada siswa kelas XI MIA SMAN 8 Mataram.

Nilai rata-rata hasil posttest yang cukup tinggi pada pembelajaran menggunakan jurnal belajar dikarenakan jurnal belajar mampu merefleksikan proses pembelajaran yang dialami siswa sehingga baik siswa maupun guru mampu melihat kekurangan, kelebihan dan peningkatan selama proses pembelajaran tersebut berlangsung. Jurnal belajar yang digunakan pada kelas eksperimen juga berfungsi sebagai sarana untuk memfasilitasi proses identifikasi kesulitan belajar siswa yang belum dimengerti oleh siswa dalam proses pembelajaran. Siswa yang dapat mengetahui kesulitan belajarnya lebih awal juga dapat lebih cepat melakukan upaya untuk mengatasi kesulitan belajar tersebut, sehingga pada saat posttest berlangsung maka seluruh konsep yang belum dipahami telah teratasi dan mempengaruhi hasil belajar menjadi lebih baik.

Hasil penelitian ini sejalan dengan penelitian yang dilakukan oleh David dan Hull (dalam Ross, 2011) yang menunjukkan bahwa terjadi peningkatan nilai posttest siswa yang menuliskan jurnal belajar selama 12 hari. David dan Hull menyimpulkan bahwa jurnal belajar mampu meningkatkan ingatan siswa dalam proses pembelajaran berdasarkan apa yang telah siswa tuliskan pada jurnal tersebut. Selain itu, sejalan dengan penelitian yang telah dilakukan oleh Anggraini (2010) bahwa penggunaan jurnal belajar berpengaruh terhadap hasil belajar. Hasil 


\section{Chemistry Education Practice,3 (1), 2020 - 4}

Nurkhasanah, Haris, Siahaan

belajar siswa yang menggunakan jurnal belajar pada akhir proses pembelajaran lebih tinggi bila dibandingkan dengan siswa yang tidak menggunakan jurnal belajar.

Hasil jurnal belajar yang telah diisi siswa menunjukkan pengalaman belajar siswa selama proses pembelajaran kimia sebanyak lima pertemuan. Pada tiap pertemuan siswa diberikan jurnal belajar dan diisi dengan jawaban yang sesuai dengan pertanyaan yang diajukan pada jurnal belajar. Melalui jurnal belajar, siswa dapat menuliskan apa yang mereka pikir, lihat atau dengar serta mampu menyampaikan mengenai suatu hal yang mereka pelajari dan pikirkan. Selain itu, jurnal belajar dapat digunakan untuk guru dalam membantu siswanya belajar secara mandiri dan sebagai bahan evaluasi guru untuk mengetahui seberapa jauh pemahaman siswa terhadap materi yang telah dipelajari.

\section{KESIMPULAN}

Berdasarkan hasil penelitian maka dapat disimpulkan bahwa kelas eksperimen yang diberi perlakuan dengan menerapkan pembelajaran jurnal belajar memiliki nilai ratarata, nilai terendah, nilai tertinggi, dan ketuntasan klasikal lebih tinggi daripada kelas kontrol yang tidak diberi perlakuan pembelajaran menggunakan jurnal belajar serta pembelajaran menggunakan jurnal belajar pada pelajaran kimia materi hidrokarbon memberikan hasil belajar yang lebih baik daripada tanpa menggunakan jurnal belajar pada siswa kelas XI MIA SMAN 8 Mataram.

\section{SARAN}

Bagi guru bidang studi kimia dan siswa dapat menerapkan jurnal belajar dalam proses pembelajaran kimia. Bagi peneliti berikutnya diharapkan agar mampu mengembangkan jurnal belajar dan menerapkannya pada materi lainnya.

\section{DAFTAR PUSTAKA}

Anggraini, S.D. 2010. Pengaruh Penerapan Jurnal Belajar dalam Model Pembelajaran Interaktif Terhadap Hasil Belajar Fisika Siswa Kelas VII SMP Negeri 8 Sungai Penuh. FKIP Universitas Jambi.

Ardiyansyah, A., Junaidi, E., dan Hadisaputra, S. 2019. Pengaruh Penerapan Model Pembelajaran Kooperatif Tipe Student Team Achievement Division (STAD) Berbantuan Lembar Kerja Siswa (LKS) Terhadap Hasil Belajar Kimia. Jurnal
Chemistry Education Practice. 2(2): 4448.

Arikunto, S. 2010. Prosedur Penelitian Suatu Pendekatan Praktek (Edisi Revisi 2010). Jakarta: Rineka Cipta.

Azwar, S. 2013. Reliabiltas dan Validitas. Yogyakarta : Pustaka Pelajar.

Darmawan, D. dan Permasih. 2013. Kurikulum \& Pembelajaran. Jakarta: Rajawali Pers

Lianto., Jufri, A. W., dan Merta, I W. 2018. Pemanfaatan Model Jurnal Belajar Kotak Berhias Untuk Meningkatkan Motivasi dan Hasil Belajar. Prosiding Seminar Nasional Pendidikan Biologi. (1). 500504.

Muhsin, L. B., Sukib., dan Laksmiwati, D. 2019. Pengaruh Model Pembelajaran Think Talk Write (TTW) Berpikir Bicara Menulis Terhadap Hasil Belajar Siswa Pada Mata Pelajaran Kimia Materi Koloid. Jurnal Chemistry Education Practice. 2(2): 3643.

Ross, N. 2011. Reflective Writing: An Approach to Developing Critical Thinking and Proficient Writing. Thesis. United States Military Academic.

SSudjana, N. 2002. Penilaian Hasil Proses Belajar Mengajar. Bandung: Remaja Rosdakarya.

Sugiyono. 2017. Statistika untuk Penelitian. Bandung: Alfabeta.

Sunyono., Wirya, I W., Suyanto, E., dan Suyadi, G. 2009. Identifikasi Masalah Kesulitan dalam Pembelajaran Kimia Kelas X di Propinsi Lampung. FKIP Universitas Bandar Lampung.

Supriadi, S., Ibnu, S., \& Yahmin, Y. (2018). Analisis model mental mahasiswa pendidikan kimia dalam memahami berbagai jenis reaksi kimia. Jurnal Pijar MIPA, 13(1), 1-5.

Wati, A., Sutopo., dan Susilo H. 2016. Implementasi Jurnal Belajar Dalam Pembelajaran Sains. Pros. Semnas Pend. IPA Pascasarjana UM. (1): 856-864. 